\title{
Update on the distribution of Phallus drewesii (Phallales, Basidiomycota): new record from Asia
}

\section{Trierveiler-Pereira $\mathrm{L}^{1}$ and Thao $\mathbf{N P}^{2}$}

\author{
${ }^{1}$ Programa de Pós-Graduação em Botânica, Universidade Federal do Rio Grande do Sul, Porto Alegre, Brazil. \\ Lt_pereira@yahoo.com.br \\ ${ }^{2}$ Department of Botany, Southern Institute of Ecology, Vietnam Academy of Science and Technology (VAST), \\ Hochiminh City, Vietnam.npthao.tnsv@gmail.com
}

Trierveiler-Pereira L, Thao NP 2013 - Update on the distribution of Phallus drewesii (Phallales, Basidiomycota): new record from Asia. Mycosphere 4(5), 994-997, Doi 10.5943/mycosphere/4/5/12

\begin{abstract}
This paper reports a new record from Asia of Phallus drewesii, a phalloid species previously only known from the African Island of São Tomé (Atlantic Ocean). A description and color photographs are provided based upon the Vietnamese specimens. Differences from similar species are briefly discussed.
\end{abstract}

Key words - Gasteromycetes - Paleotropical mycota - Phallaceae - stinkhorns.

\section{Introduction}

Phallus Junius ex L. is a well known gasteroid genus found worldwide (Kirk et al. 2008). Although some species occur in temperate regions, most members of the genus are found in tropical and subtropical areas, being South East Asia the center of diversity (Kreisel 1996). While some morphospecies have a pantropical distribution, e.g. P. indusiatus Schltdl., P. rubicundus (Bosc) Fr. and $P$. callichrous (Möller) Lloyd, others seems to have a strong endemism.

Examples of species reported from the Paleotropical regions are: $P$. caliendricus Dring, $P$. cinnabarinus (W.S. Lee) Kreisel, P. echinovolvatus (M. Zang, D.R. Zheng \& Z.X. Hu) Kreisel, P. flavocostatus Kreisel, P. formosanus Kobayasi, P. lauterbachii (Henn.) Kreisel, P. macrosporus B. Liu, Z.Y. Li \& Du, P. nanchangensis Z.Z. He, P. rubrovolvatus (M. Zang, D.G. Ji \& X.X. Liu) Kreisel, P. taibeiensis B. Liu \& Y.S. Bau, P. tenuis (E. Fisch.) Kuntze, and P. yunnanensis (M. Zang \& R.H. Petersen) Kreisel (Cunnigham 1931, Boedijn 1932, Kobayashi 1937, Dring \& Rayner 1967, Liu 1984, Kreisel 1996, Zang et al. 1998, Hosaka 2010, 2012). Phallus multicolor (Berk. \& Broome) Cooke and P. merulinus (Berk.) Cooke are also native from the Old World, but they have been reported from other areas, probably introduced by man (Reid 1977, Kreisel 1996, Cheype 2010).

To date, eleven phalloids have been reported from Vietnam, being four of them Phallus species: P. aurantiacus Mont., P. indusiatus, P. multicolor, P. rubicundus (Bosc) Fr. (Kiet 1998). Recently, several xylophilous phalloid specimens were collected in the country and identified as $P$. drewesii, which is a new record for the Asian mycota. Here, we present macro and microscopic description of these specimens, and color photographs. 

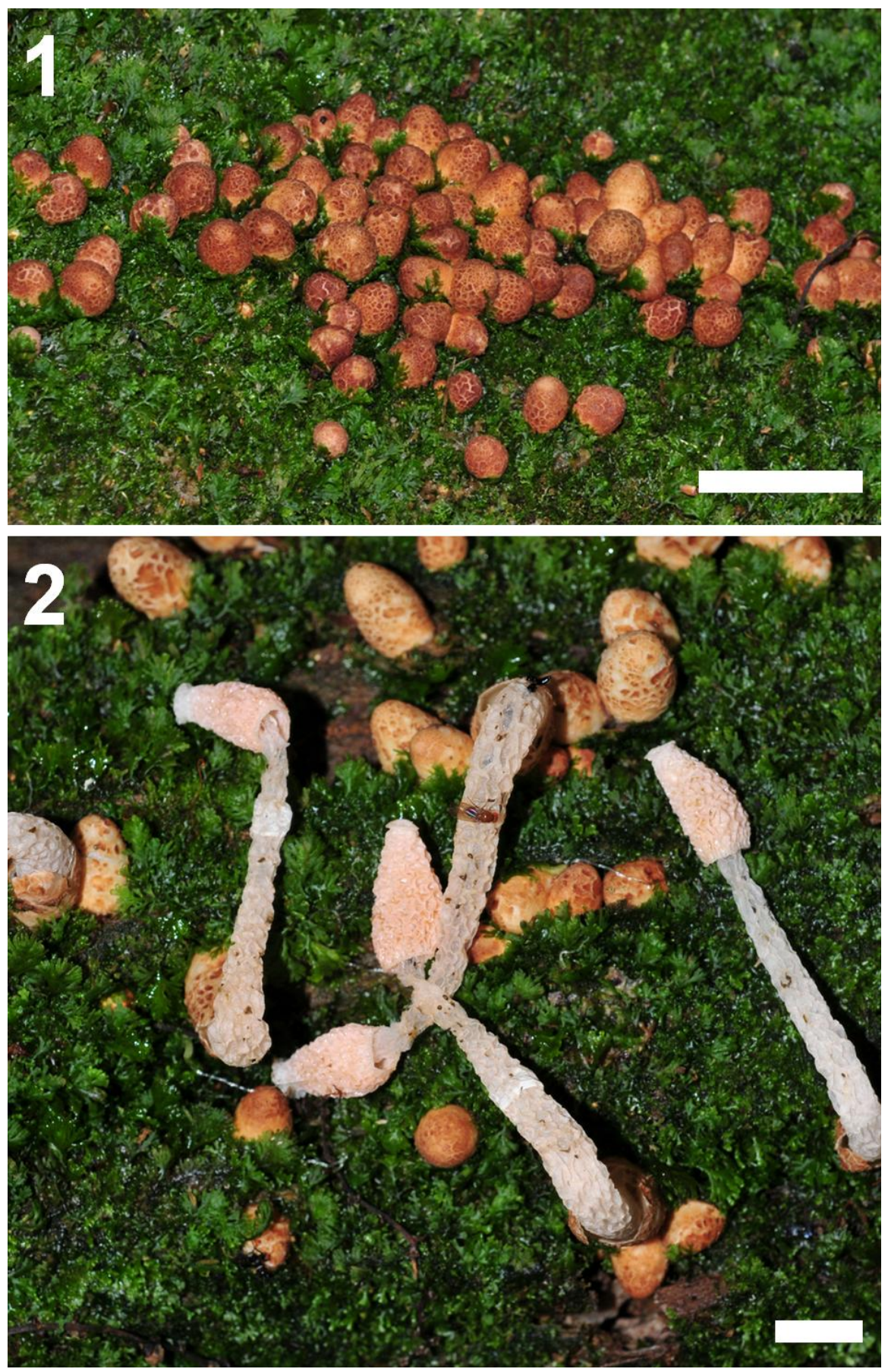

Figs 1-2 - Phallus drewesii in situ. 1 Unexpanded basidiomata. 2 Expanded and unexpanded basidiomata. - Bars $=1 \mathrm{~cm}$. Photographs are copyright of HungNguyen.

\section{Materials \& Methods}

Field expeditions have been carried out in Bidoup Núi Bà $\left(12^{\circ} 00^{\prime}\right.$ to $12^{\circ} 52^{\prime} \mathrm{N}, 108^{\circ} 17^{\prime}$ to $108^{\circ} 42^{\prime} \mathrm{E}$ ), a Vietnamese National Park with 66,047 hectares. Almost $91 \%$ of this area is covered with mostly primary forests of different kinds, including middle-mountain evergreen, coniferous broad-leaved mixed forest, high-mountain dwarf forest, mossy forest, bamboo, savanna and others (http://bidoupnuiba.gov.vn). Fungal specimens were photographed in the field, and later were slowly dried in laboratory.

Specimens were examined according to traditional techniques on gasteromycetes taxonomy (Miller \& Miller 1988). Colors were coded according to Kornerup \& Wanscher (1978) and referred to dry material, unless otherwise stated. Voucher material is kept at Herbaria SGN and ICN (Thiers 2011). 


\section{Results}

Phallus drewesii Desjardin \& B.A. Perry, Mycologia 101(4): 545 (2009).

Figs $1-2$

Unexpanded basidiomata ovoid to subglobose, $0.3-1.5 \mathrm{~cm}$ high $\times 0.3-0.8 \mathrm{~cm}$ diam., pale yellow (4A3) to light yellow (5A4), with brownish (6E4) to dark blond scales (5D4); mycelial strands attached to the base, dirty white, branched, up to $2.7 \mathrm{~cm}$ in length. Expanded basidiomata up to $7 \mathrm{~cm}$ high; pseudostipe decurved, tapering towards the apex, $2.0-4.6 \mathrm{~cm}$ high $\times 0.2-0.5 \mathrm{~cm}$ diam.; surface deeply reticulate, with more or less polygonal reticulations, whitish when fresh, light yellow when dried (4A4); receptacle conical to narrow conical, with a flat tip and a conspicuous pore at the apex (pore up to $0.3 \mathrm{~cm}$ in diam.), surface deeply reticulate, dull yellow (3B3) to yellowish gray (3B2) under the gleba. Gleba mucilaginous, olive brown (4F4), fetid.

Basidiospores cylindrical, usually attenuate at one side, 3.2-4.0 $\times 1.2-1.8 \mu \mathrm{m}$, faintly greenish tinted in $\mathrm{KOH}$, smooth, thin-walled. Receptacle and pseudostipe composed of pseudoparenchymatous hyphae, globose, sugblobose to irregular in shape, up to $48 \mu \mathrm{m}$ in diam., hyaline, thin-walled. Volva externally composed of hyaline, interwoven hyphae.

Habitat - lignicolous.

Known distribution - Paleotropical (Desjardin \& Perry 2009; present study).

Material examined -Vietnam, Lâm Đồng province, Bidoup Núi Bà National Park, Giang Ly station, growing gregarious on mossy decaying bark, 17 Jun 2013, N.P. Thao, VN-05 (SGN, ICN).

Notes - Phallus drewesii is characterized by small gregarious basidiomata growing on rotten wood. The immature forms are ovoid, yellowish to brownish; and mature forms have a whitish, deeply reticulate pseudostipe and receptacle (Desjardin \& Perry 2009). Other small xylophilous Phallus species found in the Paleotropics are: P. tenuis, P. tenuissimus T.H. Li, W.Q. Deng \& B. Liu, and P. minusculus Kreisel \& Calonge, but all of them have spongy pseudostipe. Phallus tenuis and P. tenuissimus are Asian species (Cunningham 1931, Boedijn 1932, Liu 1984, Imazeki et al. 1988, Li et al. 2005) and basidiomata have yellowish pseudostipe and receptacle. Phallus minusculus is an African species recently described from Tanzania (Kreisel \& Calonge 2002).

In the Neotropics, the only small xylophilous phalloid known to occur is Xylophallus xylogenus (Mont.) E. Fisch. (Fischer 1933, Sáenz \& Nassar 1982, Gómez \& Gazis 2006, Cheype 2010, Trierveiler-Pereira \& Silveira 2012), and it can be easily separated from $P$. drewesii due its smaller basidiomata (up to $15 \mathrm{~mm}$ high, including the volva) and smooth receptacle. A key to small xylophilous phalloid species was presented by Trierveiler-Pereira \& Silveira (2012).

\section{Acknowledgements}

This study had financial assistance from the project TN3/T09 within the Vietnam National Key Programme KHCN-TN3/11-15 (Central Highland Programme No. 3). We also acknowledge NLX Bach and NN Hung for their support.

\section{References}

Boedijn KB. 1932 - The Phallineae of the Netherlands East Indies. Bulletin du Jardin Botanique de Buitenzorg, Sér. III 12, 71-103.

Calonge FD, Kreisel H. 2002 - Phallus minusculus sp. nova from tropical Africa. Feddes Repertorium 113(7-8), 600-602.

Cheype J-L. 2010 - Phallaceae et Clathrus récoletés en Guyane française. Bulletin Mycologique et Botanique Dauphiné-Savoie 197, 51-66.

Cunningham GH. 1931 - The gasteromycetes of Australasia X. The Phallales, part I. Proceedings of the Linnean Society of New South Wales 56, 1-15.

Desjardin DE, Perry BA. 2009 - A new species of Phallus from São Tomé, Africa. Mycologia 101(4), 545-547. 
Dring DM, Rayner RW. 1967 - Some gasteromycetes from Eastern Africa. Journal of East African Natural History 26, 5-46.

Fischer E. 1933 - Gastromyceteae Stahelianae. Annales Mycologici 31(3), 113-125.

Gómez LD, Gazis R. 2006 - Dos Gasteromycetes (Basidiomycotina, Fungi) del Perú. Brenesia 65, 71.

Hosaka, K. 2010 - Preliminary list of Phallales (Phallomycetidae, Basidiomycota) in Taiwan. Memoirs of the National Science Museum National Science Museum, Tokyo 46, 57-64.

Hosaka, K. 2012 - Preliminary list of Phallales (Phallomycetidae, Basidiomycota) in Thailand. Memoirs of the National Science Museum National Science Museum, Tokyo 48, 81-89.

Imazeki R, Otani Y, Hongo T. 1988 - Fungi of Japan [in Japanese]. Yama-Kei, Tokyo.

Kiet TT. 1998 - Preliminary checklist of macrofungi of Vietnam. Feddes Repertorium 109(3-4), 257-277.

Kirk PM, Cannon PF, Minter DW, Stalpers JA. 2008 - Ainsworth \& Bisby's Dictionary of the Fungi. CABI Europe, Wallingford.

Kobayashi Y. 1937 - Fungi Austro-Japoniae et Micronesiae. I. The Botanical Magazine, Tokyo $51,749-758$.

Kornerup A, Wanscher JH. 1978 - Methuen Handbook of Colour. 3rd Ed. Eyre Methuen, London.

Kreisel H. 1996 - A preliminary survey of the genus Phallus sensu lato. Czech Mycology 48(4), 273-281.

Li TH, Liu B, Song B, Deng WQ, Zhou TX. 2005. A new species of Phallus from China and $P$. formosanus, new to mainland. Mycotaxon 91, 309-314.

Liu B. 1984 - The Gasteromycetes of China. Beihefte zur Nova Hedwigia 76, 1-235.

Miller Jr. OK, Miller HH. 1988 - Gasteromycetes: morphological and development features with keys to orders, families, and genera. Mad River Press, Eureka.

Reid DA. 1977 - Some Gasteromycetes from Trinidad and Tobago. Kew Bulletin 31(3), 657-690.

Sáenz JA, Nassar M. 1982 - Hongos de Costa Rica: Familias Phallaceae y Clathraceae. Revista de Biología Tropical 30(1), 41-52.

Thiers B. 2011 [continuously updated] - Index Herbariorum: a global directory of public herbaria and associated staff. New York Botanical Garden's Virtual Herbarium. http:// sweetgum.nybg.org/ih/ (accessed 17 September 2013).

Trierveiler-Pereira L, Silveira RMB. 2012 - Notes on Xylophallus xylogenus (Phallaceae, Agaricomycetes) based on Brazilian specimens. Mycotaxon 120, 309-316.

Zang M, Zheng D-r, Hu Z-x. 1998 - A new species of the genus Dictyophora from China. Mycotaxon 33, 145-148. 